\title{
Efektivitas Pelayanan Publik Program Mobile Customer Service on Call (MCS-OC) pada Badan Penyelenggaraan Jaminan Sosial Kesehatan Kota Jambi
}

\author{
Nuraini $^{1 *}$, Mhd. Ansori ${ }^{2}$, Gebi Chica Lorenza ${ }^{3}$ \\ 1,2,3 Fakultas Hukum Universitas Batanghari Jambi \\ Jalan Slamet Riyadi Broni Kota Jambi Telp: (0741) 65351 \\ *Corrrespondence email: nuraini.fh@unbari.ac.id; mhd.ansori@unbari.ac.id; gebylorenza@yahoo.co.id
}

\begin{abstract}
Abstrak. Penelitian ini bertujuan untuk mengetahui dan menganalisa faktor yang mempengaruhi, kendala dan solusi, serta efektivitas pelayanan publik program Mobile Customer Service On Call (MCS-OC) pada Badan Penyelenggaraan Jaminan Sosial (BPJS) Kesehatan Kota Jambi. Metode penelitian yang digunakan adalah penelitian yuridis empiris, penelitian yang dilakukan pada fakta hukum yang ada dengan melakukan observasi secara langsung ke lapangan guna mengetahui pelaksanaan serta perihalperihal yang timbul dan disesuaikan dengan peraturan perundang-undangan. Berdasarkan hasil penelitian, diketahui bahwa efektivitas pelayanan publik program Mobile Customer Service On Call (MCS-OC) pada Badan Penyelenggaraan Jaminan Sosial (BPJS) Kesehatan Kota Jambi sudah cukup efektif karena sudah mencapai segala faktor pengukuran keefektifan layanan serta informasi yang diperoleh.
\end{abstract}

Kata kunci: Efektivitas, MCS-OC, BPJS

Abstract. This study aims to identify and analyze the influencing factors, constraints and solutions, as well as the effectiveness of public services for the Mobile Customer Service On Call (MCS-OC) program at the Jambi City organizer of the health social security (BPJS). The research method used is juridical empirical research, research which is carried out on existing legal facts by making direct observations in the field in order to determine the implementation and any matters that arise and are adjusted to the laws and regulations. Based on the results of the research, it is known that the effectiveness of public services for the Mobile Customer Service On Call (MCS-OC) program at the Jambi City organizer of the health social security (BPJS) is quite effective because it has achieved all the factors that measure the effectiveness of services and the information obtained.

Keywords: Effectiveness, MCS-OC, BPJS

\section{PENDAHULUAN}

Salah satu kegiatan yang dilaksanakan untuk pemenuhan kebutuhan dasar yang disesuaikan bersama hak warga Negara, yaitu layanan yang bertautan dengan publik. Hal ini diberikan dengan harapan berguna untuk memenuhi hak masyarakat dalam bentuk layanan sipil ataupun publik, dengan asas dapat mencapai hak yang dimiliki setiap warga Negara secara individual maupun kelompok.

Setelah berjalannya otonomi daerah, pelayanan publik menjadi penting karena termasuk salah satu ukuran hasil dari pelaksanaan pemerintahan. Urusan pemerintahan yang bersangkutan dengan kepentingan masyarakat sangat penting maka dari itu mesti diperhatikannya upaya peningkatan pelayanan. Penyelenggaraan layanan masyarakat ialah salah satu kelayakan yang diemban oleh pemerintah untuk terwujudnya kesejahteraan sebagai barometer tata kelola pemerintahan yang koperatif.

Layanan publik juga sebagai jembatan agar dapat mengetahui fungsi dari suatu Negara yang bertautan dengan pemecahan dan pemenuhan keinginan masyarakat. Keharusan dari berbagai keunikan layanan publik yang harus disiapkan pemerintah disesuaikan dengan Undang-Undang yaitu publik yang primer (excellent service) secara literalnya dimaksud pelayanan yang sangat unggul atau layanan terkemuka. Barometer pelayan prima ini ialah sesuai dengan standar layanan yang berperan atau dipunyai oleh instansi yang membagikan layanan. ${ }^{1}$

Dasar hukum pelayanan publik di Indonesia ialah Undang-Undang Nomor 25 Tahun 2009 tentang Pelayanan Publik. Berdasarkan Undang-Undang Nomor 25 Tahun 2009, dikatakan secara spesifik, tujuan dirumuskannya aturan tentang layanan publik ialah sebagai berikut:

1. Terlaksananya batasan serta ikatan yang nyata antara hak tanggung jawab, keharusan dan kapasitas semua pihak terkait antara penyelenggara layanan publik.

2. Terwujudnya metode layanan publik yang layak atas asas-asas lumrah pemerintahan serta koorporasi yang aman dan unggul.

3. Terpenuhinya penyediaan layanan publik cocok dengan aturan pada per Undang-undangan.

${ }^{1}$ Sutopo, Adi Suryanto. 2003. Pelayanan Prima, Modul Pendidikan dan Pelatihan Prajabatan Golongan I dan II. Jakarta: Lembaga Administrasi Negara. hlm 12. 
Nuraini, Mhd. Ansori dan Gebi Chica Lorenza, Efektivitas Pelayanan Publik Program Mobile Customer Service on Call (MCS-OC) pada Badan Penyelenggaraan Jaminan Sosial Kesehatan Kota Jambi

4. Terwujudnya pengamanan serta kepastian hukum bagi masyarakat untuk pelaksanaan pelayanan publik.

Di dalam situasi penyelenggaraan layanan publik, Negara ialah pihak awal dan utama,yang bertanggung jawab dalam upaya pemuasan hak-hak masyarakat. Dengan muncul nya sistem otonomi, maka pemerintah daerah merupakan ujung tombak layanan publik daerah. Dibagikannya otonomi pada daerah memperkenankan proses desentralisasi, tidak terlepas dari tujuan Negara. Hal ini artinya otonomi mempunyai sejumlah fungsi terkait atas haluan pemberian otonomi. ${ }^{2}$

Gambaran layanan publik yang diinginkan oleh otonomi daerah ialah layanan publik yang meraih diri bersama pihak yang dilayani. Tata aturan layanan yang diharapkan dan di inginkan bagi penduduk yaitu layanan yang cepat (faster), murah (cheaper), serta baik (better). Untuk mencapai yang di mau dan di inginkan para pesrta yang dilayani, fasilitator layanan wajib lebih dekat (closer), lebih cepat (faster) dan lebih baik (better). ${ }^{3}$

Layanan kesehatan ialah hak yang diperoleh rakyat Indonesia yang pelaksanaanya harus dilaksanakan oleh pemerintah yang terdapat pada Undang-Undang Dasar Negara Republik Indonesia Tahun 1945 Pasal 28 H ayat (1) "Setiap manusia berhak hidup sejahtera lahir serta batin, bertempat tinggal, serta mencapai ruang lingkup yang baik dan sehat bahkan berhak mendapatkan layanan kesehatan." serta Pasal 34 ayat (3) "Negara bertanggung jawab atas ketersediaan fasilitas layanan kesehatan dan fasilitas layanan umum yang unggul".

Undang-Undang Nomor 40 Tahun 2004 tentang Sistem Jaminan Sosial Nasional (SJSN) yang di hadirkan pemerintah masa itu menerangkan bahwa jaminan sosial diharuskan bagi semua penduduk masyarakat indonesia, tergolong Jaminan Kesehatan Nasional (JKN). JKN masa ini dijalankan melalui suatu badan pemerintahan yang disebut Badan Penyelenggara Jaminan Sosial (BPJS), yang digandrungi oleh Undang-Undang Nomor 24 Tahun 2011 tentang Badan Penyelenggara Jaminan Sosial. Pemerintah menerbitkan 2 (dua) Badan Penyelenggara Jaminan Sosial (BPJS) yaitu BPJS Kesehatan serta BPJS Ketenagakerjaan. BPJS Kesehatan melangsungkan program jaminan kesehatan dan BPJS Ketenagakerjaan melangsungkan program jaminan atas kecelakaan kerja, kematian, Jaminan pensiun dan Jaminan hari tua.

BPJS dalam melaksanakan programnya masih belum membuahkan hasil yang optimum, begitu juga yang dinantikan dari pemerintah yang melaksanakan jaminan kesehatan nasional. Kejadian yang memuai di Negara kini ialah susahnya akses layanan kesehatan bagi penduduk Indoensia. Hal ini bukan saja terjadi di perkotaan tetapi juga sampai keseluruh penjuru perdesaan.

Selain dari itu faktor penyebab lainnya ialah sumber daya manusia yang terukur minimum mengakibatkan keterbatasan informasi, seumpama tentang aturan hak serta keharusan penduduk sebagai peserta yang menginginkan layanan medis agar terhindar dari hal yang tidak dinantikan, misalnya layanan dari team medis yang tidak menyenangkan, penyalahgunaan, serta lain-lainnya. Dalam penyelenggaraan pola kesehatan yang dilaksanakan oleh BPJS terdapat 3 (tiga) pihak yang berkaitan ialah BPJS Kesehatan, Peserta BPJS Kesehatan, serta Fasilitas Kesehatan mitra BPJS kesehatan.

Corona Virus Disease (COVID-19) merupakan pandemi global sedang muncul dan membawa akibat signifikan ke perubahan seluruh penjuru dunia terkait faktor adalah ekonomi, sosial hingga kehidupan sehari-hari dan layanan publik. Pemerintah telah mengekspansi langkah-langkah untuk menangani pandemi global yaitu COVID-19, dengan menyampaikan berbagai kebijakan-kebijakan seperti social distancing, work from home dan dilanjutkan dengan physical distancing. Hal tersebut membuat instansi layanan publik membatasi layanan dan menginisiasi layanan online, hal ini bertujuan agar layanan publik tetap berjalan. Penyelenggara layanan publik lalu membuat inovasiinovasi untuk memberikan layanan agar pelayanan tidak terhambat, dan kini dilakukan oleh BPJS Kesehatan Kota Jambi.

Pendekatan sistem akses layanan administrasi kepesertaan kepada masyarakat dan peserta, BPJS Kesehatan Jambi selalu memperhatikan protokol keamanan COVID-19, BPJS kesehatan memberikan layanan melalui sistem Mobile Customer Service On Call (MCS OC). Pelayanan ini ada untuk tetap memenuhi kebutuhan masyarakat yang tetap tinggi pada layanan mobile customer service pada masa COVID-19. Layanan MCS-OC merangkum layanan pendaftaran, administrasi perubahan data, pencetakan kartu peserta dan penyampaian keluhan peserta.

Sistem Mobile Customer Service On Call (MCS OC) mempunyai persyaratan khusus agar peserta dapat melakukan transaksi, yaitu layanan minimal dilakukan untuk 10 kepala keluarga, masyarakat harus melakukan penjadwalan dengan pihak BPJS Kesehatan untuk melakukan kegiatan MCS-OC dilaksanakan dengan jadwal yang ada. Pada BPJS Kesehatan Kota Jambi pada masa layanan yang dilakukan di Kantor masih terdapat beberapa keluhan

\footnotetext{
${ }^{2}$ Muhaimin. 2018. Penguat Penyelenggaraan Pelayanan Publik Melalui Penyelesaian Sengketa Informasi Publik. Jakarta: Jurnal Ilmiah Kebijakan Hukum Vol.12, No.2.

${ }^{3}$ Mulyanto dan Abdul. 2016. Penerapan Standar Pelayanan Publik Pada Kelurahan di Kota Kediri. Surabaya: Jurnal Hasil Penelitian LPPM UNTAG Vol.01, No.02.
} 
mengenai sistem layanan yang berkaitan dengan pemberian layanan berbeda-beda, lalu sistem administrasi yang kurang teratur, kurangnya tenaga kerja yang melayani para peserta dan antrian cukup lama.

Berdasarkan uraian diatas, dan untuk menghindari kajian yang terlalu luas dan menyimpang dari objek penulisan ini, maka penulis membatasi permasalahan terkait "Bagaimana faktor yang mempengaruhi, kendala dan solusi, serta efektivitas pelayanan publik program Mobile Customer Service On Call (MCS-OC) pada Badan Penyelenggaraan Jaminan Sosial (BPJS) Kesehatan Kota Jambi”

\section{METODE}

Dalam tulisan ini, tipe penelitiannya adalah penelitian yuridis empiris, yaitu penelitian yang dilakukan pada fakta hukum yang ada dengan melakukan observasi secara langsung ke lapangan guna mengetahui pelaksanaan serta perihal-perihal yang timbul ${ }^{4}$ dan disesuaikan dengan peraturan perundang-undangan. Tehnik Pengumpulan data melalui Field Research dan wawancara. Field Research adalah penelahaan terhadap sumber data berdasarkan lapangan sebagai data primer dengan kajian utamanya yaitu penemuan data langsung dari hasil wawancara oleh pihak yang telah disepakati sebagai sampel, dan Library Research adalah data yang diperoleh bedasarkan hasil kepustakaan sebagai data pendukung. Kemudian Metode analisis data bersifat kualitatif, yaitu penelitian yang mengacu pada norma hukum yang terdapat pada peraturan perundang-undangan dan putusan pengadilan serta norma-norma dalam masyarakat. Selanjutnya bahan hukum yang digunakan terdiri dari bahan hukum sekunder dan bahan hukum primer. Bahan hukum Penelitian ilmu hukum itu adalah penelitian yang berupaya mengamati fakta-fakta hukum dan sosial yang berlaku di tengah-tengah masyarakat, dalam hal ini mengharuskan pengetahuan untuk dapat diamati dan dibuktikan secara terbuka, walaupun dalam teorinya hipotesis itu ditarik dari landasan teori atau kajian pustaka, di mana dasar berpikirnya adalah logika deduktif namun pada prakteknya tidak boleh mengabaikan proses berpikir induktif. $^{5}$

\section{HASIL DAN PEMBAHASAN \\ Faktor Mempengaruhi Program MCS-OC}

Public Service merupakan konsep layanan untuk masyarakat yang dilakukan secara demokratis, adil, merata, tidak diskriminatif, jujur serta responsibilitas dengan mengayomi hak-hak rakyat dan mewujudkan tanggung jawabnya kepada masyarakat dengan mengutamakan kepentingan masyarakat untuk dijadikan pegangan atau slogan pemerintah.Sesuai dengan Undang-Undang Nomor 25 Tahun 2009 tentang Layanan Publik, penyelenggara berkewajiban menyusun dan menetapkan penunjang layanan dengan memperhatikan kompetensi penyelenggara, kebutuhan masyarakat, dan keadaan lingkungan.

Efektivitas layanan dalam cara untuk mengelevasi layanan untuk masyarakat spesifik ialah layanan kesehatan, dalam perolehan suatu efektifnya persiapan yang jelas ditujukan. Kesehatan adalah hal yang pertama bagi semua warga negara maka dari itu pemerintah sangat berkedudukan penting dalam perkembangan kesehatan masyarakat melalui kenaikan layanan kesehatan bagi rakyat. Efektivitas kerja sebuah kelompok sangat bergantung dari efektivitas kinerja dari para karyawan. Beberapa standar yang bisa digunakan untuk menakar efektivitas kerja dari badan pemerintahan yang menerima layanan, antara lain: ${ }^{6}$

1. Faktor waktu

Faktor waktu disini ialah cepat serta tepat waktu dari layanan yang dibagikan oleh pemberi layanan. Namun penerapan ukuran tepat atau cekat tidaknya layanan yang dibagikan berlainan dari satu orang ke orang lainnya, terkait dari keinginan layanan masing-masing. Kecekatan layanan yang diperoleh masyarakat bisa membantu peningkatkan kepuasan masyarakat untuk mendapatkan layanan efektif, dengan hadirnya Mobile Customer Service On Call (MCS-OC) adalah suatu keringanan untuk membagikan pelayanan serta informasi yang diterima masyarakat dengan cekat dan juga dalam waktu yang tepat.

2. Faktor kecermatan

Faktor kecermatan juga bisa dijadikan petunjuk barometer dalam menilai jenjang efektivitas kerja badan pemerintahan yang membagikan layanan untuk masyarakat. kinerja kecermatan ini bisa dilihat dari sisi ketelatenan dari pemberi layanan untuk masyarakat. Ketelitian petugas dalam membagikan informasi untuk masyarakat, juga bisa diinisiasi tingkat keefektivan layanan serta informasi yang diberikan kepada masyarakat.

3. Faktor gaya pemberian layanan

Gaya pemberian layanan membuat salah satu yang menjadi barometer yang dapat serta terkadang digunakan untuk menakar efektivitas kinerja. Gaya pemberian layanan cara serta kebiasaan dalam membagikan pemberi layanan dalam memberikan jasa kepada masyarakat. Kesopanan serta sikap ramah dan santun teruntuk masyarakat sebagai

\footnotetext{
${ }^{4}$ Peter Mahmud Marzuki,2006, Metode Penelitian Hukum. Jakarta: kencana, hal. 141.

${ }^{5}$ Bahder Johan Nasution, Metode Penelitian Ilmu Hukum, Mandar Maju, Bandung, 2008, Hal. 124.

${ }^{6}$ Sondang, Siagian, 2010, Filsafat Administrasi, Jakarta: PT Toko Gunung Agung, hlm.60.
} 
penerima layanan, juga bisa memberikan rasa nyaman sewaktu masyarakat mendapatkan sebuah layanan oleh Mobile Customer Service On Call (MCS-OC).

Beberapa faktor tersebut dapat disimpulkan, efektivitas adalah suatu konsep yang mana bisa digunakan sebagai sarana untuk menakar sebuah keberhasilan suatu badan pemerintahan, yang bisa diwujudkan dengan memperhatikan faktor tenaga, biaya, waktu, sarana, prasarana, resposibilitas, serta akses yang tetap diperhatikan risiko suatu keadaan yang dihadapi.

Tercapainya layanan yang efektif bisa menjadi sebuah barometer kualitasnya sebuah layanan yang dilaksanakan oleh pemerihtah Indonesia. Dalam peningkatan layanan publik khususnya bagian kesehatan BPJS Kesehatan memiliki suatu ide terbaru terpaut JKN-KIS ialah Mobile Customer Service On Call (MCS-OC), tujuan adanya sistem MCS-OC ini bisa menekan tingkat ramainya antrian masyarakat di kantor BPJS Kesehatan, daripada itu banyak juga manfaat yang didapat melalui sistem MCS-OC ini, di awali dari mendaftar serta mengubah format data kepersertaan, untuk mendapatkan informasi peserta serta data-data keluarga, memberi informasi terkait tagihan iuran. Dalam memberikan layanan serta informasi kepada peserta dan rakyat wajib sesuai dengan standar prosedur yang sudah dipatenkan serta dalam tergapai efektivitas layanan harus melingkupi cepat, singkat serta bermutu.

Berdasarkan hasil penelitian, sudah dilakukan pernyataan bahwa efektivitas layanan serta informasi yang dibagikan kepada rakyat melalui Mobile Customer Service On Call (MCS-OC) sangat cukup efektif, karna banyak diungkapkan oleh masyarakat yang memakai Mobile Customer Service On Call (MCS-OC), sebagaimana yg disampaikan oleh Ibu Rizki Lestari, "Dalam pemberian layanan kami sudah mengusahakan dengan cepat, tepat dan memuaskan untuk masyarakat, karena disini kami dituntut untuk memiliki komitmen terkait dengan layanan, tetapi terlepas dari itu semua kami juga menggantungkan kepada situasi maupun kondisi yang ada." " Dan pendapat Bapak Syirot sebagai penerima layanan, yang menyatakan bahwa "Layanan yang saya terima kecepatan dan ketepatan waktu layanannya cukup baik." 8

Dari pernyataan informan diketahui bahwa kepastian waktu layanan menjadi kendala dalam kinerja layanan terhadap masyarakat dengan adanya keluhan dari masyarakat tentang kepastian waktu penyelesiaian layanan. Ketepatan waktu yang diharapkan berkaitan dengan proses atau penyelesaian, jaminan dan menanggapi keluhan. Dalam menciptakan layanan yang efektif dapat dilihat dari jumlah peserta yang telah menggunakan program BPJS yaitu sebagai berikut:

Tabel 1

Peserta BPJS Kesehatan Kota Jambi

\begin{tabular}{cc}
\hline Tahun & Jumlah Peserta \\
\hline 2019 & 629.168 \\
2020 & 626.536 \\
\hline
\end{tabular}

Sumber: BPJS Kesehatan Kota Jambi

Dari sekian banyak jumlah peserta BPJS Kesehatan Kota Jambi, akan tetapi masih banyak masyarakat yang belum memakai sistem MCS-OC ini disebabkan belum mengerti menggunakan sistem MCS-OC tersebut. terdapat juga beberapa jumlah kendala pada pelaksanaan sistem MCS-OC ini adalah jaringan masih minim terbatas akan tetapi sejauh ini layanan serta informasi yang dibagikan sudah sangat baik serta masyarakat merasa puas atas layanan serta informasi yang dibagikan. berikut:

Adapun jumlah peserta yang mengikuti program MCS-OC pada BPJS Kesehatan Kota Jambi adalah sebagai

Tabel 2

Peserta MCS-OC Pada BPJS Kesehatan Kota Jambi

\begin{tabular}{|c|c|}
\hline Bulan & Jumlah Peserta \\
\hline Januari & 1.567 \\
\hline Februari & 2.679 \\
\hline Maret & 1.119 \\
\hline Juli & 11 \\
\hline Agustus & 15 \\
\hline September & 15 \\
\hline
\end{tabular}

Sumber: BPJS Kesehatan Kota Jambi

\footnotetext{
${ }^{7}$ Wawancara dengan Rizki Lestari, Kepala BPJS Kesehatan Jambi, Pada 18 Desember 2020.

${ }^{8}$ Wawancara dengan Syirot sebagai penerima layanan BPJS Kesehatan Jambi, Pada 18 Desember 2020.
} 
Berdasarkan tabel 2 dapat dilihat dalam tahun 2020 hanya 6 bulan aktif melakukan kegiatan MCS-OC, hal ini tergantung dari permintaan peserta. Pada Juli hingga September dilakukan hanya di satu Kelurahan. Hal ini berarti kurangnya minat peserta dalam melaksanakan kegiatan MCS-OC yang mungkin dipicu oleh beberapa faktor, salah satunya ialah faktor efektifitas.

Ada 3 (tiga) faktor yang merupakan ukuran dalam memperkirakan efektif atau tidak suatu layanan serta informasi yang dibagikan, ialah: Waktu, Kecermatan dan Gaya Pemberian Layanan. Dalam akhir penelitian dari observasi serta juga wawancara bersama peserta BPJS dan beberapa staf BPJS Kesehatan layanan yang dibagikan melalui Mobile Customer Service On Call (MCS-OC) sudah memenuhi ketiga faktor tersebut sebagaimana yang disampaikan oleh Ibu Rizki Lestari:

"Layanan serta informasi yang kami dibagikan sudah cepat, hanya tetapi terjadi kendala tergantung pada daerah yang menerima serta keadaan jaringan yang stabil, tetapi jika jaringan masih kurang stabil kemungkin bisa terjadi keterlambatan satu hingga dua hari, hingga saat ini layanan yang dibagikan sudah baik serta pada waktu sesuai, layanan serta informasi juga memenuhi faktor kecermatan, yaitu dimana layanan yang dibagikan teliti, cepat, atau cermat sudah sesuai dengan kebutuhan masyarakat, dan faktor ketiga ialah faktor gaya pemberian layanan yang meliputi ramah, sopan serta santun dalam membagikan layanan ataupun informasi yang dibagikan untuk masyarakat juga kenyamanan yang dirasakan oleh masyarakat, secara keseluruhannya bisa dapat disimpulkan, bahwa layanan serta informasi yang dibagikan melalui Mobile Customer Service On Call (MCS-OC) cukup efektif dikarnakan mencakup ketiga faktor tersebut serta banyak para masyarakat ataupun peserta merasa puas atas layanan yang dibagikan, oleh Kantor BPJS Kesehatan Jambi. ","

Dari uraian di atas, mengenai faktor yang mempengaruhi keefektifan program MCS-OC jika dihubungkan dengan teori yang disampaikan Sutrisno, ${ }^{10}$ maka ketepatan sasaran program sudah terlaksana dilihat dari antrian di kantor BPJS tidak menjadi ramai kemudian tujuan program juga sudah terlaksana, dibuktikan dengan pelayanan yang diberikan secara cepat.

\section{Kendala dan Solusi Sistem Layanan Mobile Customer Service On Call (MCS-OC)}

Berdasarkan analisa data dari hasil wawancara serta observasi pada BPJS Kesehatan Jambi dengan 3 (tiga) informan yang bertugas melayani pelayanan Mobile Customer Service On Call (MCS-OC), ditemukan beberapa masalah yang dihadapi, sebagaimana yang disampaikan oleh Ibu Rizki Lestari, "Biasanya dalam pelaksanaan MCSOC terjadi beberapa hambatan seperti sedikitnya jumlah pemohon, ketidakstabilan jaringan internet, sarana dan prasarana kurang patut dan kurangnya perencaanaan prosedur." 11

Berdasarkan penelitian dilakukan, masalah yang telah ditemukan dalam penelitian pelaksanaan program Mobile Customer Service On Call (MCS OC) dikelompokkan menjadi 2 (dua) kategori, yaitu hambatan teknik dan hambatan organisasi. Jika disamakan bersama teori Korten model kesamaan penerapan program ditemukan ketidaksamaan antara 3 (tiga) unsur pelaksanaan program. Unsur pertama dalam teori Korten menafsirkan kemiripan program dengan pemanfaat ialah kesamaan antara apa yang diajukan oleh program dengan apa yang diinginkan kelompok sasaran (pemanfaat), para peserta BPJS Kesehatan bisa mendapatkan pemberian jaminan kesehatan sangat layak serta dimudahkan dalam mendapatkan layanan kesehatan, tetapi masih ada keluhan responden mengenai pemberian jaminan kesehatan, serta juga layanan kesehatan yang belum sempurna.

Berdasarkan unsur kedua, dijelaskan kesamaan antara program dan badan pelaksana ialah, kesamaan antara tugas yang diperintahkan oleh program dengan kemampuan organisasi pelaksana yang artinya keamaan antara tugas yang diperintahkan oleh program dengan kemampuan organisasi pelaksana. Hal ini kesesuaian antara tugas yang diperintahkan program dengan kemampuan organisasi bisa dikatakan belum sesuai, sebab organisasi belum sepenuhnya memberikan kepuasan pada pasien peserta BPJS Kesehatan, dilihat dari adanya keluhan responden terhadapan layanan yang dibagikan organisasi.

Berdasarkan unsur ketiga, dijelaskan kesamaan antara kelompok pemanfaat dengan organisasi pelaksana ialah kesamaan antara syarat yang diputuskan organisasi bisa mendapat output program, dengan apa yang bisa dilakukan oleh kelompok sasaran program. Hal ini salah satu sasaran program yaitu peserta puas oleh pelayanan yang dibagikan belum sepenuhnya dirasakan oleh semua pasien peserta BPJS Kesehatan. Peserta merasa belum puas dengan pelayanan yang dibagikan seperti layanannya yang lambat, antrian yang pajnag serta lama dan sistem administrasi yang membingungkan.

\footnotetext{
${ }^{9}$ Wawancara dengan Rizki Lestari, Kepala BPJS Kesehatan Jambi, Pada 18 Desember 2020.

${ }^{10}$ Sutrisno, 2007, Manajemen Keuangan: Teori, Konsep, dan Aplikasi, Yogyakarta: Ekonisia, hlm. 125.

${ }^{11}$ Wawancara dengan Rizki Lestari, Kepala BPJS Kesehatan Jambi, Pada 18 Desember 2020.
} 
Dengan demikian belum tepat adanya antara syarat yang diputuskan oleh sebuah badan pemerintahan. Ketidaksesuaian 3 (tiga) unsur pelaksanaan program belum terlaksana dengan baik serta output yang belum sesuai dengan harapan menjadi penyebab faktor yang menghambat dalam implementasi program BPJS Kesehatan di Kota Jambi.

Selain itu, menurut pendangan responden beberapa hal faktor yang turut menjadi penghalang dalam berjalannya sebuah program BPJS Kesehatan ialah sebagai berikut:

1. Sosialisasi Program

Sosialisasi program adalah salah satu upaya, untuk membagikan informasi yang tepat kepada masyarakat khususnya untuk peserta BPJS Kesehatan. Berdasarkan para informan masih kurangnya sosialisasi yang dibagikan oleh pihak terkait. Lantas tidak jarang masih ada pengguna BPJS Kesehatan yang belum memahami seutuhnya program BPJS Kesehatan. Begitu juga masih adanya masyarakat yang belum mempunyai kartu BPJS Kesehatan atau menjadi peserta BPJS Kesehatan. Maka dari itu diinginkan BPJS Kesehatan, pemerintah serta pihak-pihak terkait mampu memberikan lalu juga dapat mengoptimalkan sosialisasi untuk seluruh lapisan masyarakat, supaya informasi mengenai program BPJS Kesehatan bisa dimengerti dan dipahami oleh masyarakat.

2. Layanan

Layanan adalah sebuah permasalahan yang masih ditemukan, cukup sering disampaikan oleh pasien peserta BPJS Kesehatan. para pasien BPJS Kesehatan sering kali tidak mendapat layanan maksimal seperti penolakan pada pasien BPJS Kesehatan, waktu layanan yang lama dan layanan untuk pemberian obat ada kalanya juga tidak sesuai dibandingkan pasien yang membayar langsung. BPJS Kesehatan dihadirkan agar masyarakat bisa terlayani secara baik termasuk di puskesmas. Oleh karena itu masyarakat lebih mudah untuk mencapai puskesmas.

Mengenai kendala dan solusi di dalam penelitian ini jika dihubungkan dengan Teori Sutrisno, ${ }^{12}$ maka masih terdapat kekurangan dalam hal pemahaman terhadap program MCS-OC. Hal ini dapat dilihat dari uraian di atas, jika masih terdapat masyarakat yang belum mengerti bagaimana cara menggunakan sistem MCS-OC tersebut dan dalam hal pemantauan yang dilakukan oleh pihak BPJS sampai saat ini hanya mengenai sistem jaringan internet yang belum memadai sehingga mengakibatkan tidak ada kepastian waktu layanan bagi masyarakat.

\section{Efektivitas Layanan Mobile Customer Service On Call (MCS-OC)}

Dalam upaya merengkuh akses layanan administrasi kepesertaan Jaminan Kesehatan Nasional-Kartu Indonesia Sehat (JKN-KIS) kepada peserta serta masyarakat, khususnya di Wilayah Kota Jambi,tetap memperhatikan protokol keamanaan covid, BPJS Kesehatan akan hadir dengan layanan Mobile Customer Service On Call (MCS-OC). BPJS Kesehatan memperkenalkan sekaligus melakukan launching layanan Mobile Customer Service On Call (MCS-OC) dengan seluruh Kepala Kecamatan yang ada di Wilayah Kota Jambi. Bertepatan dengan pelaksanaan evaluasi distribusi Kartu Indonesia Sehat Penerima Bantuan Iuran (KIS-PBI).

Kepala Bidang Kepesertaan dan Layanan Peserta Kantor Cabang Jambi, Adithia Hangga Rimartha menerangkan bahwa layanan MCS-OC ini ada untuk menjawab kebutuhan masyarakat yang tetap tinggi pada layanan Mobile Customer Service, walaupun dalam keadaan masa pandemi COVID-19. Layanan MCS-OC ini melingkupi layanan pendaftaran, administrasi perubahan data, pencetakan kartu peserta bahkan untuk memberikan pengaduan atau keluhan kita hadirkan layanan di Kantor Cabang dalam bentuk layanan mobile yang hadir ditengah- tengah warga. Sementara itu untuk syarat serta alur proses Mobile Customer Service On Call (MCS-OC) jumlah layanan minimal dilakukan untuk 10 kepala keluarga, serta melakukan penjadwalan kegiatan Mobile Customer Service On Call (MCS-OC) sesuai kesepakatan dan jadwal yang ada, lalu petugas BPJS Kesehatan akan memberikan layanan sesuai jadwal yang telah disetujui.

Efektivitas layanan dalam usahanya untuk pengembangan pelayanan bagi masyarakat khususnya layanan kesehatan, dalam perolehan suatu efektifnya pencanangan yang sudah ditargetkan. Kesehatan adalah tujuan yang utama untuk seluruh penduduk Indonesia, sebab dari itu pemerintah sangat berfungsi penting dalam peningkatan kesehatan para penduduknya melalui meningkatnya layanan kesehatan bagi para penduduk Indonesia, BPJS Kesehatan memiliki pembaruan terbaru dalam meningkatkan layanan kesehatannya, dengan hadirnya program JKNKIS( Jaminan Kesehatan Nasional-Kartu Indonesia Sehat) dimana setiap penduduk Indonesia harus memperoleh jaminan kesehatan, selain JKN-KIS BPJS Kesehatan juga mengeluarkan sistem Mobile Customer Service On Call (MCS-OC) dimana sistem Mobile Customer Service On Call (MCS-OC) diperuntukkan bagi masyarakat peserta BPJS Kesehatan yang memudahkan masyarakatnya untuk mengakses informasi ataupun layanan seputar JKN-KIS, tujuan adanya sistem Mobile Customer Service On Call (MCS-OC) ini, yaitu untuk memangkas antrian agar peserta BPJS tidak perlu lagi menunggu terlalu lama untuk datang ke kantor karena hanya dengan memanfaatkan sistem MCS-OC masyarakat atau para peserta BPJS Kesehatan bisa langsung mengakses melalui sistem Mobile Customer Service On

${ }^{12}$ Sutrisno, Loc.Cit. 
Call (MCS OC) ini. Berdasarkan fakta di lapangan, bahwa penggunaan sistem Mobile Customer Service On Call (MCS OC) ini masih sangat sedikit dan bahkan ada masyarakat yang belum mengetahui sistem MCS-OC ini, serta ada juga masyarakat yang sudah tau mengenai sistem MCS-OC tersebut, namun tidak mau menggunakan bukan karena kurangnya sosialisasi tetapi ketidak inginan masyarakat dalam penggunaan sistem MCS-OC ini.

Tujuan pencapaian layanan yang efektif bisa menjadi sebuah standarisasi kualitasnya suatu layanan yang dilaksanakan oleh pemerihtah. Dalam meningkatkan layanan publik khusunya bagian kesehatan, BPJS Kesehatan memiliki suatu inovasi terbaru terkait JKN-KIS yaitu sistem Mobile Customer Service On Call (MCS-OC), tujuan dengan adanya sistem Mobile Customer Service On Call (MCS-OC) ini bisa mengurangi antrian para peserta di kantor BPJS Kesehatan, lalu banyak juga manfaat yang didapat melalui sistem Mobile Customer Service On Call (MCS OC) ini diawali dari mendaftar serta mengubah data kepersertaan, untuk mendapatkan informasi peserta lalu data keluarga, mengetahui informasi tagihan iuran, untuk mendapatkan sistem Mobile Customer Service On Call (MCS-OC), dan menyampaikan keluhan serta permintaan informasi terkait JKN-Kis. Dalam memberikan layanan serta informasi kepada peserta dan masyarakat harus cocok dengan standar kualitas prosedur yang sudah ditetapkan dan dalam menggapai suatu efektivitas layanan harus mencakup cepat, tepat dan bermutu.

Berdasarkan hasil observasi yang sudah dilakukan, menyatakan bahwa efektivitas layanan serta informasi yang dibagikan untuk masyarakat melalui sistem Mobile Customer Service On Call (MCS-OC) sudah cukup efektif, hal ini banyak disampaikan oleh masyarakat yang menggunakan sistem Mobile Customer Service On Call (MCS-OC) tetapi masih banyak juga masyarakat yang belum menggunakan sistem Mobile Customer Service On Call (MCS-OC) ini dikarenakan belum memahami dalam menggunakan sistem Mobile Customer Service On Call (MCS-OC) tersebut. Ada juga terdapat sejumlah kendala dalam penerapan sistem Mobile Customer Service On Call (MCS-OC) ini yaitu jaringan yang sangat minimum, tetapi sejauh ini layanan serta informasi yang dibagikan sudah cukup baik dan masyarakat merasa cukup puas dengan layanan serta informasi yang dibagikan.

\section{SIMPULAN}

1. Pelayanan yang dibagikan melalui sistem MCS-OC sudah disebutkan efektif karena sudah mencapai segala faktor pengukuran keefektifan layanan serta informasi yang diperoleh.

2. Kendala yang dihadapi pihak BPJS dalam melakukan sistem MCS-OC yaitu sosialisasi program dan layanan.

3. Efektivitas layanan serta informasi yang disampaikan kepada masyarakat melalui Mobile Customer Service On Call (MCS-OC), sudah cukup efektif, hal ini banyak disampaikan oleh para peserta yang memakai Mobile Customer Service On Call (MCS-OS).

\section{DAFTAR PUSTAKA}

Sutopo, Adi Suryanto, 2003, Pelayanan Prima, Modul Pendidikan dan Pelatihan Prajabatan Golongan I dan II, Jakarta: Lembaga Administrasi Negara.

Muhaimin, 2018, Penguat Penyelenggaraan Pelayanan Publik Melalui Penyelesaian Sengketa Informasi Publik, Jakarta: Jurnal Ilmiah Kebijakan Hukum Vol.12, No.2.

Mulyanto dan Abdul, 2016, Penerapan Standar Pelayanan Publik Pada Kelurahan di Kota Kediri, Surabaya: Jurnal Hasil Penelitian LPPM UNTAG Vol.01, No.02.

Peter Mahmud Marzuki, 2006, Metode Penelitian Hukum, Jakarta: Kencana

Bahder Johan Nasution, 2008, Metode Penelitian Ilmu Hukum, Bandung: Mandar Maju.

Sondang Siagian, 2010, Filsafat Administrasi, Jakarta: PT Toko Gunung Agung.

Sutrisno, 2007, Manajemen Keuangan: Teori, Konsep, dan Aplikasi, Yogyakarta: Ekonisia.

Undang-Undang Nomor 25 Tahun 2009 tentang Pelayanan Publik.

Undang-Undang Nomor 40 Tahun 2004 tentang Sistem Jaminan Sosial Nasional

Undang-Undang Nomor 24 Tahun 2011 tentang Badan Penyelenggara Jaminan Sosial 